\title{
Sciendo
}

HOLISTICA Vol 10, Issue 3, 2019, pp. 7-26

\section{Managing ambidexterity in internationalisation of SMEs from an emerging country: A dynamic capability perspective}

\author{
Anjar, PRIYONO, \\ Department of Management, Universitas Islam Indonesia, Yogyakarta, Indonesia \\ anjar.priyono@uii.ac.id \\ Siti, NURSYAMSIAH, \\ Department of Management, Universitas Islam Indonesia, Yogyakarta, Indonesia \\ siti.nursyamsiah@uii.ac.id \\ Baziedy, A. DARMAWAN, \\ Department of Management, Universitas Islam Indonesia, Yogyakarta, Indonesia \\ baziedy@uii.ac.id
}

\begin{abstract}
Ambidexterity is the ability of firms to undertake exploration and exploitation concurrently. Empirical evidence suggests that ambidextrous organisations are better able to manage the tradeoff between flexibility and efficiency. Although ambidexterity has been the subject of many previous research studies, relatively little attention has been paid to how SMEs manage ambidexterity in an international market. A multiple case study research design was used to explore ambidexterity in two SMEs. The research utilised an inductive approach. SMEs adopt different strategies to manage ambidexterity. Larger SMEs, supported with more resources, can carry out exploration and exploitation simultaneously. By contrast, smaller sized SMEs must perform exploration and exploitation intermittently. In addition, the impacts of managers, resource flexibility, and network supports in managing ambidexterity are also discussed. This study suggests that managers of SMEs should consider resource availability and the characteristics of the international customers being served before designing a strategy for managing ambidexterity. This study contributes to the limited empirical evidence on how SMEs manage ambidexterity in international markets.
\end{abstract}

Keywords: ambidexterity; small and medium sized-enterprises; internationalization; dynamic capability; capability tensions; exploitation; exploration.

JEL Classification: M10; M16; O3.

\section{Introduction}

A persistent challenge for managers of firms is capability of maintaining a balance between exploit their current markets, while at the same time exploring 
new markets for growth. The balance between these capabilities is necessary to ensure the company is gain profit, as well as to pursue growth (O'Reilly III \& Tushman 2013). There has been plethora of studies examining ambidexterity but a number of new studies have recently emerged examining the topic from various perspectives; for example, Koryak et al. (2018) analysed how the influence of top management team composition influence the success of firms adopt ambidexterity, Pertusa-Ortega and Molina-Azorín (2018) examined factors influencing and consequences of ambidexterity, Jiménez and Boehe (2018) observed the interaction of companies with government of countries with high risk during foreign direct investment.

Previous works have also demonstrated that the success of the company achieving ambidexterity indicates that the two capabilities are complementary and can be coordinated (Voss \& Voss 2013; Mashahadi et al. 2016; Pertusa-Ortega \& Molina-Azorín 2018). Due to the conflicting nature between exploration and exploitation as well as the strategic importance of ambidexterity, top-level management must split their attention equally between exploitative and explorative activities across different units (Smith and Tushman 2005). Scholars stated that ambidexterity is part of dynamic capability (O'Reilly III \& Tushman 2008 ) because to achieve ambidexterity a company must be able to flexibly move between two conflicting capabilities (O'Reilly III \&Tushman 2008).

Empirical evidence has demonstrated that the internationalisation process and its underlying capabilities differ across industries (Mudambi \&Zahra 2007). For example, for firms operating in industries with short product life cycles and those operating in rapidly changing environments, it is important to possess distraction capabilities in order to attain high growth rates. Similarly, for companies operating in an international business environment, the number of competitors is higher and the business environment is more volatile; thus SMEs are required to have certain capabilities that enable them to adapt to such an environment (Cavusgil \& Knight 2015).

An important issue that appears not to have been addressed is how SMEs from emerging economy manage international ambidexterity. Therefore, this study aims to analyse the ambidexterity of SMEs in the context of internationalisation. The majority of previous studies have focused on ambidexterity in large-sized companies, and the number of studies observing ambidexterity in SMEs in international contexts is very limited. Previous studies observing ambidexterity have used large firms as subjects including Jiménez and Boehe (2018), Birkinshaw et al. (2016), Carter (2015), and Andriopoulos et al. (2016). Meanwhile, the studies examining SMEs have mostly addressed dynamic 
capabilities in general, with no specific focus on ambidexterity - see, for example, Pinho and Prange (2016), Cavusgil and Knight (2015), and Zhou et al. (2007). Thus, new research examining ambidexterity in SMEs internationalisation contributes to both academia and practice. Accordingly, the relevant research question addressed in this paper is: how do internationalised SMEs from emerging economy manage ambidexterity? This research will provide a novel contribution, as it analyses ambidexterity with SMEs from emerging economy operating in international markets as the subject, a topic that has received limited attention.

This paper is organised in five sections. The next section will discuss previous research pertaining to ambidexterity, particularly in SMEs. The third section will discuss the method used for conducting this research, followed by a discussion and analysis of the results in the fourth section. Finally, conclusions and suggestions for further research will be presented in the last section.

\section{Focused literature review on ambidexterity in SMEs}

A plethora of studies have revealed that ambidexterity has a positive effect on firm performance (Lubatkin et al. 2006; Raisch et al. 2009; Birkinshaw et al 2016; Mashahadi, Ahmad \& Mohamad 2016). These studies show that one of the parameters most commonly used to measure performance is sales growth (He and Wong 2004).

Implementing ambidexterity is challenging as exploration and exploitation require different learning models (Eisenhardt $\&$ Martin 2000). In addition, each requires different organisational architectures and processes, and, consequently, could necessitate a 'trade-off' (Smith \&Tushman 2005; Andriopoulos \& Lewis 2009). Due to the complexity of the issue of ambidexterity, many scholars have questioned whether it is necessary for a company to achieve a balance between exploitation and exploration, or if it is more advisable to focus on improving just one of these capabilities. The complexity of ambidexterity in strategic management intensifies when one observes the issue in SMEs, which have limited resources and thus the trade-off between exploitation and exploration becomes more obvious (Cavusgil \& Knight 2015).

Simultaneous development of the two conflicting capabilities - i.e. exploration and exploitation - requires firms to balance limited resources within the organisation (Voss and Voss 2013). Birkinshaw et al. (2016) suggest three models of adaptation in order to achieve this balance: structural separation, behavioral integration, and sequential alternation. However, they do not suggest 
choosing one model and applying it exclusively; rather, they suggest implementing one primary model, whilst simultaneously using other adaptation models to complement it.

International ambidexterity suggests that firms achieve a balance between exploitation and exploration, and avoid focusing only on either one. Focusing on either exploitation or exploration will result in a 'lock-in' situation. In such a situation, firms experience difficulties to switch from exploration to exploitation, and vice versa. Balancing the two conflicting capabilities is important for performance, as international ambidexterity is the foundation for companies to achieve sustainable performance (Prange \& Verdier 2011).

In larger companies, managing ambidexterity is easier due to the greater amount of available resources, which makes the allocation of resources to different functions more straightforward. Typically, firms establish two separate divisions tasked with fulfilling the two different needs (Lubatkin et al. 2006). As exploration comes before exploitation, this implies that companies must spend a certain amount of resource on exploration before they look to undertake exploitation. More settled exploration makes exploitation become easier and less risky (Voss \& Voss 2013). For this reason, firms are willing to spend a larger amount of resources before deciding continuing to exploitation.

The success of ambidexterity management is related to the volume of assets that a firm possesses. Ambidexterity has a positive impact on performance for larger firms, but not for smaller firms. One possible explanation for this is that larger firms have more resources, making allocation easier, as described above. However, small firm size does not always correlate to disadvantage; for instance, smaller SMEs gain benefit from being more flexible (Lubatkin et al. 2006). Furthermore, older firms adopt ambidexterity more efficiently than their younger counterparts (Voss \& Voss 2013).

SMEs have more simple organisational structure, meaning that managers must perform a number of roles simultaneously. In many cases, different functions within SMEs must be coordinated by the manager. However, their organisational structure also makes them more flexible. Flexibility enables SMEs to undertake explorations and exploitation in different markets more easily. Similarly, resources flexibility makes serving different markets more easily. Explorations and exploitations must also be well coordinated and facilitated by managers, who also serve strategic and operational roles (Lubatkin et al. 2006). 


\section{Research method: Case study}

\subsection{Case study design}

This study focuses on internationally oriented SMEs in order to obtain indepth data (Eisenhardt 1991) on exploitation and exploration of international markets. Scholars suggest that the development of theory using an inductive approach is most appropriate to answer 'how' type questions (Eisenhardt 1989; Voss et al. 2002; Yin 2009). Furthermore, Edmondson and McManus (2007) argue that the development of theory using an inductive approach is considered suitable if the observed phenomenon is new and little research has previously been conducted in that field. This research conducted case studies of two SMEs undertaking international business; each case was treated as a separate entity, to allow researchers undertaking cross-case analysis to observe patterns in the data (Eisenhardt 1989; Yin 2009).

There is no precise rule for determining the ideal number of cases in multiple case study research. In the case study method, the composition of the cases, as subjects of the investigation, is more important than the number. A case should be included as an subject of observation due to its potential contribution to the study (Eisenhardt 1989). For this study, a multiple case study design with a holistic unit of analysis was selected to enable the researcher to utilise direct and indirect replication logic (Yin 2009). Typically, researchers expect that the results of replication logic can be generalised across different objects and situations (Eisenhardt 1989; Yin 2009). Data collection, data analysis, and the drawing of conclusions were undertaken iteratively until saturation was achieved (Eisenhardt 1989; Yin 2009).

\subsection{Case selection}

This research is exploratory in nature, which aims to develop a theory, and uses a multiple case study multiple case study design - instead of a single case study - in order to produce a more generalisable theory although with a consequence of complex research process (Eisenhardt \& Graebner 2007). 
In case study research, a subject is selected based on theoretical sampling, whereas survey research is based on statistical samples (Eisenhardt 1989; Yin 2009; Creswell 2014).

The selection of subjects in the case study should consider whether the sample may contribute new insights and enable the proposed research questions to be answered in sufficient detail (Meredith, 1998). This is in contrast to survey research, where the subjects are selected as representatives of the population (Yin 2009). A brief overview of the two anonymised case companies selected for this research is presented in Table 1 . The table demonstrated that there are certain variations between the case companies so that allow the researchers to conduct direct and indirect replication logic (Eisenhardt, 1989; Eisenhardt \& Graebner 2007).

\subsection{Data collection and analysis}

Data collection was undertaken through interviews, observation and focus group discussions to allow researchers gain a deep understanding regarding topics under investigation. To analyse the data, the researchers utilised grounded theory as a method of analysis (Bamford 2008): open coding, axial coding, and selective coding (Glaser \& Strauss 2017). NVivo software was used to support the data analysis, particularly in the first stage of the data analysis, in which a large number of topics emerged. The use of data collected from various sources, such as was the case in this study, allows researchers to undertake triangulation so that research validity is assured (Yin 2009).

Table 1. A brief cross-case analysis of the case companies

\begin{tabular}{|c|c|c|}
\hline Focus of analysis & BatikCo. & HandicraftCo. \\
\hline $\begin{array}{l}\text { Governance and } \\
\text { organisation } \\
\text { structure }\end{array}$ & $\begin{array}{l}\text { The firm has well established } \\
\text { organisation structure, headed by } \\
\text { a manager appointed by the } \\
\text { owner. As many as } 75 \text { full time } \\
\text { employees working at the } \\
\text { company. The firm focuses of } \\
\text { offering a wide range of fashion } \\
\text { products made of batik. }\end{array}$ & $\begin{array}{l}\text { The firm manage } 44 \text { people to } \\
\text { manufacture various handicrafts. The } \\
\text { employees, who are mostly working } \\
\text { on part time basis, are recruited } \\
\text { temporarily based on the availability } \\
\text { of orders from market. }\end{array}$ \\
\hline $\begin{array}{l}\text { International } \\
\text { market } \\
\text { engagement }\end{array}$ & $\begin{array}{l}\text { The firm export as much as } 90 \% \text { of } \\
\text { its products to Japan, USA, } \\
\text { Australia, France, England and } \\
\text { Holland. Most products sold to } \\
\text { foreign market are in bulk lot sizes }\end{array}$ & $\begin{array}{l}\text { The firm serves both local and } \\
\text { foreign market, with the latter more } \\
\text { dominant than the former. Products } \\
\text { are exported to European countries, } \\
\text { Australia, USA and Japan through }\end{array}$ \\
\hline
\end{tabular}




\begin{tabular}{|c|c|c|}
\hline & $\begin{array}{l}\text { while those for local market use } \\
\text { retail distribution channels } \\
\text { managed by the firm. }\end{array}$ & $\begin{array}{l}\text { intermediaries who facilitates a } \\
\text { number of SMEs in reaching foreign } \\
\text { market. }\end{array}$ \\
\hline $\begin{array}{l}\text { Distribution } \\
\text { channel for local } \\
\text { customers }\end{array}$ & $\begin{array}{l}\text { Local customers view the firm's } \\
\text { products as luxury so that they } \\
\text { eager to purchase at high price. }\end{array}$ & $\begin{array}{l}\text { Products are marketed to local } \\
\text { customers are distributed through } \\
\text { retail outlets, who order to the firm } \\
\text { in small batches. }\end{array}$ \\
\hline $\begin{array}{l}\text { Type of } \\
\text { transactions } \\
\text { with customers }\end{array}$ & $\begin{array}{l}\text { Mostly Business to Business (B2B) } \\
\text { transaction }\end{array}$ & $\begin{array}{l}\text { B2B is more dominant than Business } \\
\text { to Customers (B2C). }\end{array}$ \\
\hline $\begin{array}{l}\text { Contact with } \\
\text { customers } \\
\text { abroad }\end{array}$ & $\begin{array}{l}\text { The firm made direct contact with } \\
\text { customers from abroad due to the } \\
\text { experience of the managers } \\
\text { pursuing career abroad. }\end{array}$ & $\begin{array}{l}\text { The firm does not have direct contact } \\
\text { with customers abroad due to lack of } \\
\text { foreign market knowledge. The firm } \\
\text { use intermediaries to contact with } \\
\text { customers abroad. }\end{array}$ \\
\hline
\end{tabular}

\section{Empirical findings}

The literature emphasises that, traditionally, international business has been the domain of large companies, which are supported with abundant resources. The emergence of SMEs in the international market is in line with the concept of the 'accelerated global firm'. The two case study companies selected as the subjects of this study are both SMEs that are not supported with abundant resources. Rather, the companies have both successfully entered the international market due to their uniqueness, their ability to innovate, and their ability to leverage business networks.

The external business environment has also contributed to their internationalisation success, such as the growth of the middle class, the support of a wider network of suppliers of ideas and knowledge from abroad, and the convenience of facilities that enable them to reach customers abroad. This section will describe how both case companies achieved ambidexterity in pursuing international business.

\subsection{BatikCo.}

BatikCo. is an SME engaged in the batik industry, producing a large variety of fashion items. The diversity of its products shows that the company has engaged in intensive innovation. Approximately $90 \%$ of the firm's products are targeted at international markets, with the remainder sold locally. The distribution channels 
the firm uses to serve its international market are dominated by the B2B system, while in the local market the company mostly uses B2C and direct selling.

Due to the high diversity of product demands from international customers, the firm tries to incorporate innovation as part of its business process. Several strategies have been employed to facilitate innovation, such as using designers from abroad, registering a trademark in the USA, and, more recently, the company also attempted to register a copyright in the USA. Local product designers appear to experience difficulties in understanding the needs of a foreign market. Overseas designers have better knowledge that enables them to do this, particularly in terms of product design for their own country. For example, a designer from Japan has successfully combined a traditional batik pattern with Japanese motifs, such as sakura flowers and Buddhist temples.

To exploit the international market, the firm not only creates innovative products, but also incorporates certain uniqueness into its products. For example, as mentioned previously, the firm produces fashion items that combine traditional batik patterns with references to Japanese culture. Meanwhile, for English customers, the firm manufactures batik patterns that are combined with the symbols of Premier League football clubs. When creating new product designs, the details are scrutinised to ensure that the new products launched are able to satisfy customers' needs. The ability to interpret the needs of customers is thus a critical success factor for the firm, as it is operating under a 'make-to-order' system.

When entering a new market in a foreign country, the firm prepares a specific resource configuration. The managers of the company claim that innovative products alone are not sufficient to enable the company to succeed in overseas markets. Dedicated product development teams for exploiting new markets consist of individuals from different functions encompassing production, research and development, marketing, and accounting. The firm strives to hold regular meetings to ensure that its strategy continues to be in line with the needs of the business environment. One of the challenges encountered during organising resource is how to define appropriate resource configuration due to firm's limited resources. It can be said that during the exploration stage the firm relies on the manager, while the majority of the exploitation is delegated to the staff and teams.

In the resource configuration, there are several parties involved in the process of delivering value to customers; of these, distributors, agents, and wholesalers are the most important partners for the firm to deliver products to customers abroad. These partners not only play a role in delivering products to customers, but also as parties that support the exploitation of foreign markets. 
These parties also provide new product ideas and give feedback on existing products to the firm.

Finding new agents and distributors is part of the firm's explorative strategy. It is more advantageous for companies to find agents and distributors than to look for markets; this is because agents and distributors will join the company's supply chain, which can then expand the market by finding new customers. Again, the search for partners relies on the role of the manager.

BatikCo. carries out exploration and exploitation activities simultaneously. Explorations, which are aimed at identifying opportunities in foreign countries, are initiated by the manager. The manager, who is also the owner, is the most knowledgeable individual within the firm regarding the foreign market. The concept design for new products is also mostly driven by the manager. Then, the manager creates a team to convert the concept design into a tangible product. However, the team often experiences difficulties in translating customer desires into products. Under such conditions, the manager again is able to identify what customers really want. The manager also assesses the final product before it is launched. This evidence indicates that the manager has attempted to integrate innovation into routine business processes, but it seems that this effort has not been as successful as expected.

The role of managers is clearly critical to the success of internationalisation. In this case company, the manager acts not only as a manager, who is responsible for day-to-day operations - i.e. exploitative activities - but also as an entrepreneur, who seeks new opportunities in foreign markets. In this case company, the role of the manager in carrying out exploitative activities could be delegated to staff, but he cannot appoint his staff to undertake his role for explorative activities. This indicates the critical role of the manager in the exploration of new markets.

BatikCo.'s exploration of the internationalisation market is risky, as it relies on the role of the manager, as explained previously. The manager is the only individual in the company who possesses the knowledge required for undertaking exploration of the international market, and to some extent also for exploitation. Thus, reaching the international market is highly dependent on the manager; it has not become entirely routine and embedded within the formal organisational structure.

BatikCo. uses information technology platforms to support its B2B and B2C business. The information technology is used for both market exploitation and exploration, for communication with potential customers abroad, for proposing 
product samples, proposing new designs, and offering contract agreements. The manager also uses professional networks to find opportunities abroad, such as the type of products customers are demanding, distribution networks, and exhibition opportunities. These professional networks, which have been accumulated from the manager's previous experience, enable the company to more easily reach potential markets abroad.

\subsection{HandicraftCo.}

HandicraftCo. is an SME engaged in the handicraft industry. The company manufactures a large variety of interior decoration products made of synthetic leather. Most products are produced on a make-to-order basis for customers from various countries, including Japan, America, Australia, France, England, Holland, and others. With limited tangible assets, the owner seeks to optimise the utilisation of the company's intangible assets. In some cases, the utilisation of these intangible assets can offset the limited volume of tangible assets. One of the firm's most valuable intangible assets is the knowledge of handicraft production techniques, which has been accumulated through experience. However, this knowledge is embedded in the manager, who is also the founder. The manager attempt to shares this knowledge with employees with the purpose of improving efficiency during the production process, as well as ensuring that products meet quality standards.

HandicraftCo. manages 28 third-party partners to outsource its production in case of increasing demands from the market. The partners are mostly former employees of the firm, who left to set up their own businesses. These parties are closely monitored by the firm to ensure that the products they manufacture meet the company's quality standards. These partners are not involved in any exploration activities, as they focus on exploitation by manufacturing handicrafts. In short, the firm uses other parties to exploit the foreign market.

The owner strives to identify and build networks with distributors and vendors abroad. As an SME with limited human resources, the firm relies on the manager to develop international business networks, as the only individual who possesses knowledge regarding exploration of the international market. Thus, the role of the owner, who also acts as the manager, is dominant during new market exploration.

Examination of the number of company partners for international market exploration reveals interesting findings. The number of partners involved in foreign market exploration is limited; the company has two vendors, which 
communicate frequently with the owner. This figure is much lower in comparison to partners for product manufacturing - i.e. 28 firms - indicating that the firm places greater emphasis on exploiting existing markets over exploring new markets.

In contrast to larger companies, which tend to perform explorative and exploitative activities iteratively, SMEs such as HandicraftCo. adopt a different approach. As mentioned previously, HandicraftCo. rarely undertakes exploration. Exploration is only undertaken when existing customers are no longer placing orders with the firm. As soon as HandicraftCo. reaches its desired market through exploration, the firm begins to focus solely on serving the just-discovered market.

The decision to use this approach was based on limited resource availability; the firm's resources are almost entirely allocated to serving the existing market. In addition, exploration requires more resources than exploitation. The firm will thus carry out exploration only when existing customers terminate their sales contract, or the firm has an excess of resources that must be utilised.

HandicraftCo. thus can be said to undertake exploration and exploration activities intermittently and interchangeably. For example, in an extreme case, it takes nearly three months for the company to undertake exploration with the aim of reaching new markets; then, after finding a new market, the company returns to an exploitative approach. The firm attempts to spend as little time and resources on exploration as possible, and instead strives to optimise exploitation to the greatest possible extent.

In the interviews, it was revealed that the firm experiences difficulties in maintain long-term relationships with customers abroad. Thus, once the firm has exploited customers in a particular country for a certain period of time, their market becomes saturated. In such circumstances, the company has two options: offer product innovation, or explore new markets. Of these options, the firm prefers the former, as it is more efficient and involves lower risk.

Where the firm does undertake exploration to find new markets, the purpose is to replace a saturated market, not to achieve company growth. It is important to note here that deciding that a particular market (i.e. in a certain country) has reached saturation and thus the firm should leave that market, is a critical issue. If the market has reached saturation, the longer the firm remains in that market, the higher the financial burden it will face; thus, the firm must leave these markets quickly. The ability to leave certain countries and exit a market is a 
part of dynamic capability. Leaving a country can thus be considered as a strategy for survival (Cavusgil and Knight 2015).

\section{Analysis and results}

From the within-case analysis presented in the previous section, we identified a number of patterns, which are summarised in Table 2 . The next section will discuss in more detail the contents of the table.

\subsection{The international networks developed by the manager}

The critical role played by the manager during exploration is apparent in BatikCo. In this company, once the manager has identified new markets, exploitation is delegated to a team consisting of staff from across different functions. The role of the manager is in overseeing the way in which exploration is executed and providing feedback. A strong team has been formed in this firm, and new market exploitation, to some extent, has become routines. It is the team that is responsible for carrying out exploitation, under the supervision of the manager, who ensures that the market desires have been properly translated by the team. By contrast, in HandicraftCo., the role of manager appears to be more dominant in market exploitation. The processes of product design, production, and quality control, are tasks that remain under the control of the manager. These findings confirm the concerns of scholars that certain capabilities are possessed by certain people and are difficult to embed within organisational routines (Teece 2012).

Table 2. Ambidexterity analysis of the case companies

\begin{tabular}{|c|c|c|}
\hline Strategies & BatikCo. & HandicraftCo. \\
\hline $\begin{array}{l}\text { 1. The } \\
\text { international } \\
\text { networks } \\
\text { developed by } \\
\text { the manager }\end{array}$ & $\begin{array}{l}\text { 1.1. Manager relies on personal and } \\
\text { professional networks to build } \\
\text { long-term contracts - the } \\
\text { networks are developed } \\
\text { through overseas trade fairs } \\
\text { that the company participates } \\
\text { in, experiences gained from } \\
\text { large companies as third-party } \\
\text { producers, and } \\
\text { recommendations from } \\
\text { government officials. }\end{array}$ & $\begin{array}{l}\text { 1.1. Manager relies on personal } \\
\text { networks to build short-term } \\
\text { contracts. Most activities are } \\
\text { intended for exploitation. }\end{array}$ \\
\hline
\end{tabular}


1.2. The manager's major role is in exploration, while in the exploitation stage his role is as a controller.

2. Resource allocation and intensity

3. Resource configuration and market exploitation
2.1. Firm performs exploitative and explorative functions simultaneously with approximately identical intensity.

2.2. The firm can maintain relationships with international customers for a relatively long time, which enables it to exploit markets and generate profit.

3.1. The firm has organise certain resource configuration each different market. The manager organises an 'orchestra' using available resources from different functions to meet unique requirement of each market

3.2. The firm has a team dedicated to designing a bespoke resource configuration for each group of customers from abroad.
1.2. Manager is responsible for both exploration and exploitation.

2.1. Companies focus on exploration and exploitation intermittently and interchangeably due to limited resource availability.

2.2. There are times when the firm does not have orders from abroad, and then it focuses on exploration.

3.1. It seems that the firm has not developed a well-established resource configuration. The resources within the company are 'fluid'; they must be fluid and easy to reconfigure to meet the needs of future customers.

3.2. The firm seems do not have sufficient resources to be allocated for various customers from different countries.

Both companies explore new markets, but with different objectives due to the differences in the firms' characteristics. The objective of BatikCo. is to expand its international market, while HandicraftCo. aims to replace saturated markets. HandicraftCo. explores new markets more often, having greater flexibility and agility compared to BatikCo., due to its relatively smaller size. However, HandicraftCo.'s decision to engage in exploration more often results in less efficient operations, as successful explorations in a new market typically require the firm to reconfigure its resources to fit with the new business ecosystem (Teece 2007).

\subsection{Resource allocation and intensity}

BatikCo. has an allocated certain resources for each market. The firm defines precisely what the customers in each market desire, and develops a 
certain resource configuration to meet this demand. In this way, the firm is able to maintain a long-term relationship with customers, and therefore, exploitation can be executed for the long term. Dynamic capability acts as an enabler for developing appropriate resource configurations; one of the reasons for this is that the organisation is dynamic and able to test, revise, and implement resource configurations. Nevertheless, the success of executing resource configurations depends greatly on the manager's ability to organise an architecture that allows asset synchronisation and supports the learning process. Equally important is organisational flexibility, which allows the firm to adjust its rources to changing needs of customers from different countries (Teece 2017).

By contrast, HandicraftCo. serves its customers through short-term relationships. The firm rarely receives identical orders for products from customers and consequently must reconfigure its resources with the purpose of finding the most optimum one.

The empirical data suggests that HandicraftCo. has a 'disruptive competence' to regularly reconfigure resources to adjust to new markets. Disruptive competence focuses on capacity-building in order to serve new customers that are different from previous customers (Teece 2014). Capabilities accumulated from previous experience might be useful for serving new customers but, in most cases, require some adjustments. Typically, firms require a longer learning process when serving new customers, but this is not the case for HandicraftCo.

\subsection{Resource configuration and market exploitation}

For large companies, implementing exploration and exploitation in the same function can be easier due to more flexible resource allocation. In SMEs, on the other hand, implementing both exploration and exploitation in the same function could lead to a trade-off between the two capabilities. Empirical evidence for this was apparent in HandicraftCo., which has more limited resources compared to BatikCo. HandicraftCo. has to focus on either exploitative or explorative activities at one time due to resource constraints. Consequently, functions within HandicraftCo. should have a certain level of flexibility to undertake both exploitative and explorative activities. This circumstance makes the learning process more difficult, as possessing particular expertise and knowledge is not well appreciated.

The trade-off between exploration and exploitation occurring in a function or department within an organisation cannot be minimised through the use of 
knowledge accumulated from the past. This condition is different from problems caused by limited tangible assets, which can be minimised through the application of accumulated knowledge and past experience past (Weerawardena et al. 2007).

In this research, it was demonstrated that both of the case firms have successfully achieved ambidexterity despite limited resource availability. It was also clear that the way a firm organises its resources and how the manager builds new configurations using existing resources is more important than the resource availability itself. In addition, tangible resources, such as production technology, machinery, and automation, which are expensive to acquire, are not often available in the case companies, as SMEs. However, the firms demonstrate effective leverage of intangible assets in the form of knowledge and networks. Possession of relevant knowledge supports companies in exploiting foreign markets and improves their competitive position within an industry.

\section{Discussion}

The results obtained from the cross-case analysis have demonstrated that the case companies have successfully managed a trade-off between exploration and exploitation. The case companies each adopt different strategies to achieve this balance and thereby achieve ambidexterity.

It has also been found that when companies experience difficulties in achieving ambidexterity, or place more emphasis on either exploration or exploitation, this will lead to 'core rigidities' (Leonard-Barton 1992). This condition causes the company to be rigid where it finds it difficult to adapt to environmental changes. Other studies examining ambidexterity have also concluded that there is a need to achieve ambidexterity in order to achieve sustainability in international business (Cavusgil \& Knight 2015).

According to organisational learning theory, companies should explore foreign countries with different cultures than those with identical or similar cultures. This theory implies that firms should concentrate on countries with similar cultures before targeting those where the culture is markedly different (Barkema \& Drogendijk 2007). However, the results of the present study indicate that it is better for companies to explore foreign countries with a different culture from the country of origin. There are many local competitors in the host countries; this is due to the fact that there are many firms producing similar products to those of the case companies. Thus, it is better for the case companies to explore countries located in different continents with different cultures. Although it is 
slightly more difficult to enter these destinations initially, the companies can reap greater benefit if they can successfully exploit these markets.

The success of SMEs in managing ambidexterity depends heavily on the managers, as entrepreneurs. The characteristics of entrepreneurs that support internationalisation include proactiveness, innovativeness, and risk-seeking behaviour (Zhou, 2007). In terms of ambidexterity, entrepreneurship is needed particularly for exploration, which involves risk-seeking behaviour. Entrepreneurship is critical to identifying emerging opportunities, initiating new directions of action, and finding better techniques for combining resources in new ways. This requires creativity to assemble dispersed resources into a coherent composition that can create competitive advantage (Teece, 2007).

Both case companies consistently attempt to achieve a compromise between exploitative and explorative activities, although they implement this using different approaches. BatikCo., which has more resources, has successfully performed exploitative and explorative functions concurrently. The firm utilises a structural approach to achieve ambidexterity, where manager focuses on exploration while the exploitation is executed by a team. Once the manager has discovered a new market abroad, the task of exploitation is delegated to a team; the manager then merely supervises the team, and is not involved in detailed implementation.

This finding differs from previous research, which has found that companies delegate the tasks of sensing and seizing to frontline employees (Birkinshaw et al. 2016). Furthermore, this study has revealed that in SMEs supported by adequate resource availability, sensing is the task of the manager, who also acts as an entrepreneur. Frontline employees do not have the ability to build market networks on an international level. This divergence from the findings of previous studies is based on several reasons.

First, most previous research has used multinational corporations as subjects (Andriopoulos \& Lewis 2009; Teece 2014; Koryak et al. 2018) while this study focused on SMEs with more limited resources, particularly human resources, which are dominated by blue collar workers. This is in contrast to multinational companies, where the majority of employees tend to be well educated. A higher level of education of employees in international companies enables them to engage in sensing activities to identify changes in the business environment.

Similar findings were achieved for both case companies in regard to their reliance on the role of the manager. Although SMEs were selected as the subjects of this study, the managers in both cases have accumulated knowledge from lengthy experience during their career. However, relying on accumulated 
knowledge has drawbacks, as this may limit the opportunities for exploration. For instance, accumulated knowledge tends to create routines with static behaviour. As a result, the decisions and actions taken by managers will not be creative, and tend to be monotonous. Company actions will follow structured patterns due to the use of references from the past, whereas environmental changes are unstructured and unpredictable.

\section{Conclusions}

In general, the evidence presented in this study suggests that the level of ambidexterity achieved in SMEs relies heavily on top-level management. It is true that some elements of the dynamic capabilities required to attain ambidexterity are embedded within the organisation itself, however the changes resulted from dynamic capabilities still rely on the top-level management, and it is the role of managers to ensure that orchestration is successful (Teece, 2012).

This study also identifies that smaller sized SMEs tend to engage in more intensive exploration than their larger counterparts. One of the explanations could be that SMEs have greater flexibility than bigger companies, and experience more difficulties maintaining existing markets. This flexibility offers advantages for SMEs, although it also creates drawbacks. For instance, firms become less efficient because they have to search for new markets more frequently in order to identify new opportunities (Teece et al. 2016); the firm must also reconfigure its resources in order to serve the new markets (Cavusgil \& Knight 2015).

This study suggests that, in light of their limited resources, SMEs should exploit markets to the greatest extent possible, as placing more emphasis on exploitation results in a more sustainable business than the explorative approach. However, exploration is also necessary, but with limited resources it is not recommended that SMEs undertake excessive exploitation. One reason for this is that explorative approaches involve higher risk than exploitative approaches.

Another factor contributing to the success of ambidexterity is the characteristics of SMEs. This study indicates that larger SMEs adopt more intensive exploitation than their smaller counterparts. The former has more resources to ensure better service; this can help maintain strong relationships with customers so that long-term exploitation can be undertaken. In addition, with more resources, employees can develop a specialism so that customers are better served. 
By contrast, smaller SMEs experience difficulties in maintaining consistent relationships with customers. With more limited resources, employees must perform various tasks without the support of specialised knowledge. Furthermore, the number of possible markets for the firm itself is limited. Consequently, explorations are undertaken frequently to find opportunities in new markets. Smaller SMEs should thus strive to focus on exploitation as far as possible, as this enables firms to take advantage of their capabilities to seize opportunities markets to the greatest possible extent and gain benefits from current products and services.

Further research could carry out longitudinal analyses to determine the pattern of ambidexterity development in relation to business growth. Through the use of longitudinal analysis, researchers can observe the changes in ambidexterity alongside the business growth of the firms being studied.

\section{Acknowledgement}

The authors would like to express gratitude to Directorate of Research, Technology \& Higher Education, Republic of Indonesia, for supporting this research under contract No. 109/SP2H/DRPM/2019.

\section{References}

[1] Andriopoulos, C. \& Lewis, M. W., (2009). Exploitation-exploration tensions and organizational ambidexterity: Managing paradoxes of innovation, Organization Science, 20(4), pp. 696-717.

[2] Bamford, D., (2008). The use of grounded theory in change management research., Journal of Change Management, 8(2), pp. 111-121.

[3] Barkema, H. G. and Drogendijk, R. (2007). Internationalising in small, incremental or larger steps?, Journal of International Business Studies, 38(7), pp. 1132-1148.

[4] Birkinshaw, J., Zimmermann, A. and Raisch, S., (2016). How do firms adapt to discontinuous change? Bridging the dynamic capabilities and ambidexterity perspectives, California Management Review, 58(4), pp. 36-58.

[5] Carter, W. R., (2015). Ambidexterity deconstructed: a hierarchy of capabilities perspective, Management Research Review, 38(8), pp. 794-812.

[6] Cavusgil, S. T. and Knight, G., (2015). The born global firm: An entrepreneurial and capabilities perspective on early and rapid internationalization, Journal of International Business Studies. Nature Publishing Group, 46(1), pp. 3-16.

[7] Creswell, J. W., (2014). Research design: Qualitative, quantitative, \& mixed approaches, 4th edition. Sage Publications, Inc., London, United Kingdom.

[8] Edmondson, A. C. and McManus, S. E., (2007). Methodological fit in management field research, Academy of Management Review, 32(4), pp. 1155-1179. 
[9] Eisenhardt, K. M., (1989). Building theories from case study research, The Academy of Management Review, 14(4), pp. 532-550.

[10] Eisenhardt, K. M., (1991). Better stories and better constructs: The case for rigor and comparative logic, Academy of Management Review, 16(3), pp. 620-627.

[11] Eisenhardt, K. M. and Graebner, M. E., (2007). Theory building from cases: Opportunities and challenges, Academy of Management Journal, 50(1), pp. 25-32.

[12] Eisenhardt, K. M. and Martin, J. A., (2000). Dynamic capabilities: What are they?, Strategic Management Journal, pp. 1105-1121.

[13] He, Z. L. and Wong, P. K., (2004). Exploration vs. exploitation: An empirical test of the ambidexterity hypothesis, Organization Science, 15(4), pp. 481-494.

[14] Jiménez, A. and Boehe, D., (2018). How do political and market exposure nurture ambidexterity?, Journal of Business Research. Elsevier, 89(February 2017), pp. 67-76.

[15] Koryak, O., Lockett, A., Hayton, J., Nicolaou, N., \& Mole, K., (2018). Disentangling the antecedents of ambidexterity: Exploration and exploitation, Research Policy, 47(2), pp. 413427.

[16] Leonard-Barton, D., (1992). Core capabilities and core rigidities: A paradox in managing new product development, Strategic Management Journal, 13(S1), pp. 111-125.

[17] Lubatkin, M. H., Simsek, Z., Ling, Y., \& Veiga, J. F., (2006). Ambidexterity and performance in small-to medium-sized firms: The pivotal role of top management team behavioral integration, Journal of Management, 32(5), pp. 646-672.

[18] Mashahadi, F., Ahmad, N. H. and Mohamad, O., (2016). Strategic innovation ambidexterity and the internationalization performance of small and medium enterprises, World Journal of Entrepreneurship, Management and Sustainable Development, 12(2), pp. 161-175.

[19] Meredith, J., (1998). Building operations management theory through case and field research, Journal of Operations Management, 16, pp. 441-454.

[20] Mudambi, R. and Zahra, S. A., (2007). The survival of international new ventures, Journal of International Business Studies, 38(2), pp. 333-352.

[21] O'Reilly III, C. A. and Tushman, M. L., (2008). Ambidexterity as a dynamic capability: Resolving the innovator's dilemma, Research in Organizational Behavior, 28, pp. 185-206.

[22] O'Reilly III, C. A. and Tushman, M. L., (2013). Organizational ambidexterity: Past, present, and future, Academy of management Perspectives, 27(4), pp. 324-338.

[23] Pertusa-Ortega, E. M. and Molina-Azorín, J. F., (2018). A joint analysis of determinants and performance consequences of ambidexterity, BRQ Business Research Quarterly. ACEDE, 21(2), pp. 84-98.

[24] Pinho, J. C. and Prange, C., (2016). The effect of social networks and dynamic internationalization capabilities on international performance, Journal of World Business, 51(3), pp. 391-403.

[25] Prange, C. and Verdier, S., (2011). Dynamic capabilities, internationalization processes and performance, Journal of World Business. Elsevier Inc., 46(1), pp. 126-133.

[26] Raisch, S., Birkinshaw, J., Probst, G., \& Tushman, M. L., (2009). Organizational ambidexterity: Balancing exploitation and exploration for sustained performance, Organization Science, 20(4), pp. 685-695.

[27] Smith, W. K. and Tushman, M. L., (2005). Managing strategic contradictions: A top management model for managing innovation streams, Organization science, 16(5), pp. 522536.

[28] Teece, D. J., (2007). Explicating dynamic capabilities: The nature and microfoundations of (sustainable) enterprise performance, Strategic Management Journal, 28, pp. 1319-1350. 
[29] Teece, D. J., (2012). Dynamic capabilities: Routines versus entrepreneurial action, Journal of Management Studies, 49(8), pp. 1395-1401.

[30] Teece, D. J., (2014). A dynamic capabilities-based entrepreneurial theory of the multinational enterprise, Journal of International Business Studies, 45(1), pp. 8-37.

[31] Teece, D. J., (2017). Business models and dynamic capabilities, Long Range Planning. Elsevier Ltd, 51(1), pp. 40-49. doi: 10.1016/j.Irp.2017.06.007.

[32] Teece, D., Peteraf, M. and Leih, S., (2016). Dynamic capabilities and Organizational agility: Risk, uncertainty and strategy in the innovation economy, California Management Review, 58(4), pp. 13-36.

[33] Voss, C., Tsikriktsis, N. and Frohlich, M., (2002). Case research in operations management, International Journal of Operations \& Production Management, 22(2), pp. 195-219.

[34] Voss, G. B. and Voss, Z. G., (2013). Strategic ambidexterity in small and medium-sized enterprises: Implementing exploration and exploitation in product and market domains, Organization Science, 24(5), pp. 1459-1477.

[35] Weerawardena, J., Mort, G. S., Liesch, P. W., \& Knight, G., (2007). Conceptualizing accelerated internationalization in the born global firm: A dynamic capabilities perspective, Journal of World Business, 42(3), pp. 294-306.

[36] Winter, S. G., (2003). Understanding dynamic capabilities, Strategic Management Journal, 24(Special Issue: Why is there a resource-based view? Toward a theory of competitive heterogeneity), pp. 991-995.

[37] Yin, R. K., (2009). Case study research: Design and methods. 4th edn. London, United Kingdom.: Sage Publications, Inc.

[38] Zhou, L., (2007). The effects of entrepreneurial proclivity and foreign market knowledge on early internationalization, Journal of World Business, 42(3), pp. 281-293.

[39] Zhou, L., Wu, W. P. and Luo, X., (2007). Internationalization and the performance of bornglobal SMEs: The mediating role of social networks, Journal of International Business Studies, 38(4), pp. 673-690. 